\title{
Impact of non-performing loans on financial performance: A case of Sri Lankan listed commercial banks
}

\author{
M.Jathurika \\ Faculty of Communication and Business studies, Trincomalee campus, Eastern \\ University of Sri Lanka.
}

\begin{abstract}
The purpose of this investigation is to extend earlier research on the impact of NonPerforming Loans on financial performance. The study confines only nine listed commercial banks in Sri Lanka through the purposive sampling due to the minimize of missing data and links secondary data derived from the annual financial reports of commercial banks using the CSE's database. The analysednon-performing loans indicator include non-performing loan ratio while financial performance indicator incudes return on assets, return on equity. Regression and Correlation analysis have been employed for the study to investigate the effects of non-performing loans on financial performance. The results of the analysis have revealed that attributeof NonPerforming Loans which is Non-Performing Loan ratio have a negative and significant impact on Financial Performance. The prominent finding of the research utterly reveals that, non-performing loans significantly influences the financial performance of listed commercial banks in Sri Lanka with the negative relationship. Based on the Finding, researcher recommends banks to devise new strategies and implement effective policies relating with managementof non-performing loans to improve their financial viability as non-performing loans is one of the significant factors that determine the financial performance which this study concluded. Thus this study will be useful for the management personnel of banks to create the ideas for protect banks from crisis and enhance the performance of banks.
\end{abstract}

Keywords- Non-performing loans, financial performance, listed commercial banks 


\section{Introduction}

The banking sector in Sri Lanka continued to expand with improved business operations and risk management practices with the implementation of timely and appropriate regulatory measures and it continued to support economic growth and development through enhanced banking services. (Central bank report, 2017). The banking sector is considered to be an important means of financing for most infant businesses. By its nature, banks face numerous risks which arises as a result of its dynamic operations, and the complexity of the economic environment in which it operates (Ebenezer \& Omar, 2016).

Efficient intermediation of commercial banks is vital for developing economics in order to achieve higher economic growth, while insolvency of them leads to economic crisis. However, intermediation function of commercial banks gives rise to different types of risks with different magnitudes and level of causes on bank performance such as credit risk, liquidity risk, market risk, operational risk etc (Van Gestel\&Baesens, 2008).

Gizaw, Kebede, and Selvaraj, 2015; Abu Hussain and Al-Ajmi, (2012) have asserted in their studies that among the risks in banking operation, credit risk is found to be important determinant of bank performance. Meanwhile NonPerforming Loans ratio (NPLs ratio) is the major indicator of credit risk of commercial banks. It represents how much of banks loans and advances are becoming non-performing which measures the extent of credit default risk that the bank sustained (Gizaw, Kebede and Selvaraj, 2015).

Non-Performing Loans is the possibility of a borrower defaulting an unpaid loan either partly or in full (Basel Committee on Banking Supervision, 2001), this was integrated by Ahmad and Ariff (2007), he also extended that NPLs is a percentage of loans that are not repaid within three months (90 days).

Numerous recent studies from different countries like Ethiopia, Nigeria, Bangaladesh and UK involved with the topic of credit risk and non-performing loans on the financial performance of banks and the studies concluded with significant outcomes as well.

Samuel, (2015); Noman, Pervin, Chowdhury and Banna, (2015); Kolapo, Ayeni and Oke, (2012); Ebenezer and Omar, (2016); Rasika and Sampath, (2015). Abiola and Olausi, (2014) employed the Non-Performing Loans ratio (NPLs ratio) in the study to measure Non- Performing loans and found that Non- Performing loans have 
significant impact on theperformance of commercial banks as a credit risk indicator. While in the context of Sri Lanka, Rasika and Sampath, (2015) also asserted with the findings that credit risk remains a major concern for the commercial banks in Sri Lanka because credit risk is an important predictor of bank's financial performance by employed the Non-Performing Loans ratio (NPLs ratio) as one of the indicator of credit risk.

Thus researcher could be able to observe that the concept of Non-Performing Loansgets robust impact in the banking industry of both developed and developing countries particularly after the advent of 2007-2008 financial crises. Saeed and Zahid,(2016) also indicates that over the last ten years quality of the loan and its portfolios across many economics worldwide stayed comparatively stable until the emergence of 2007-2008 financial crises.

But prior studies evidenced a mix and inconclusive results i.e. Samuel, (2015); Noman, Pervin, Chowdhury and Banna, (2015); Kolapo, Ayeni, and Oke, (2012); Ebenezer and Omar, (2016); Rasika and Sampath, (2015) from Sri Lanka concluded the findings with significant and negative effect of Non- Performing loans on the financial performance of banks.
On contrary a quite number of researchers found out significant and positive effect of Non-performing loans on the financial performance (Saeed and Zahid, 2016; Aruwa and Musa, 2014; Adeusi, Akeke, Adebisi and Oladunjoye, 2014). Besides, Kithinji, 2010 expressed there is no any association with Non-performing loans and performance of Kenyan commercial banks.

As such, the research question has been arisen as "what is the association with Non-performing loans and financial performance?" while extensive studies have focused on Europe and African countries (Saeed and Zahid, 2016; Ebenezer and Omar, 2016; Gizaw, Kebede and Selvaraj, 2015) only a few numbers of researches have been conducted in the context of Sri Lanka which reinforce the researcher to investigate the association of NonPerforming loans with financial performance considering commercial banks in Sri Lanka. Thus the current study aimed at contributing to the literature gap by examines the impact of Non-Performing loanson financial performance using recent annual reports.

This paper is organised as follows: Section 2 presents a review of the empirical studies that investigate the association between Non-Performing 
loans on financial performance of listed Commercial Banks in Sri Lanka, Section 3 explains the Methodology, Section 4 focuses on the findings and interpretation and Section 5 presents the conclusion of the study and recommendations.

\section{Literature review and hypotheses}

According to the Annual reports of Commercial banks in Sri Lanka, Commonly Credit Risk is defined as the risk that the Bank will incur a loss because its customers or counterparties fail to discharge their contractual obligations.

Non-Performing Loans is the possibility of a borrower defaulting an unpaid loan either partly or in full (Basel Committee on Banking Supervision, 2001), this was integrated by Ahmad and Ariff (2007), he also extended that NPLs is a percentage of loans that are not repaid within three months (90 days).

Non-Performing Loans ratio (NPLs ratio) is the major indicator of credit risk of commercial banks. It represents how much of banks loans and advances are becoming non-performing which measures the extent of credit default risk that the bank sustained (Gizaw, Kebede\&Selvaraj, 2015).
Noman, Pervin, Chowdhury and Banna, (2015) pointed out Non-Performing Loans ratio (NPLs ratio) is considered as one of the most important indicator of credit risk and loan quality of the bank. Lower the ratio is the indication of better asset quality and lower doubtful loan, therefore lower credit risk. The following researches also employed Non-Performing Loans ratio (NPLs ratio) as the prominent proxy of credit risk. (Rasika and Sampath, 2015; Saeed and Zahid, 2016; Aruwa and Musa, 2014; Adeusi, Akeke and Oladunjoye, 2014)

The impact of non-performing loans on the financial performance of commercial banks has been the concern of emerging studies both in developed and developing countries. Abiola and Olausi, (2014) employed nonperforming Loans ratio as a credit risk indicator. Using a regression model, the findings of the study revealed that nonperforming loans have a significant impact on the profitability of commercial banks' in Nigeria. This conclusion comply with the researches of Kargi, 2011; Musyoki and Kadubo, 2012; Hosna, Manzura and Juanjuan, 2009; Gizaw, Kebede and Selvaraj, 2015.

Numerous studies concluded the findings with significant and negative effect of non-performing loans on the 
financial performance of banks (Samuel, 2015; Noman, Pervin, Chowdhury \&Banna; Kolapo, Ayeni\&Oke, 2012; Ebenezer \& Omar, 2016; Rasika\&Sampath, 2015 from Sri Lanka). On contrary a quite number of researchers found out significant and positive effect of non-performing loans on the financial performance (Saeed and Zahid, 2016; Aruwa and Musa, 2014 and Adeusi, Akeke, Adebisi and Oladunjoye, 2014).

Besides, some researches expressed there is no any association with credit risk and profitability. Kithinji, (2010) examined Credit risk management and profitability of commercial banks in Kenya. The findings revealed that the bulk of the profits of commercial banks are not influenced by the amount of credit and nonperforming loans suggesting that other variables other than credit and non-performing loans impact on profits.

The literature review suggests that most of the studies focused on the European and African countries, only a few studies have focused on the context of Sri Lanka. Further it extends only the analysis of impact has focused in the context of Sri Lanka. Besides, most of the studies gives the hope of significant impact of non-performing loans on the financial performance of banks (Samuel, 2015; Noman, Pervin,
Chowdhury \&Banna; Kolapo, Ayeni\&Oke, 2012; Ebenezer \&Omar, 2016; Kargi, 2011; Musyoki\&Kadubo, 2012; Hosna, Manzura\&Juanjuan, 2009; Gizaw, Kebede\&Selvaraj, 2015; Rasika\&Sampath, 2015 from Sri Lanka). Based on the literature support following hypothesis could be formulated:

Hypothesis 1: There is a significant impact of Non-performing loans on Financial Performance of Commercial banks in Sri Lanka.

Hypothesis 2: There is a significant relationship between Non-Performing loans and Financial Performance of Commercial Banks in Sri Lanka.

\section{Methodology}

The quantitative research approach is employed to find out the result of the study. In order to test the research hypotheses, the statistical tools used include the person's correlation analysis and regression analysis. Here correlation analysis will be used to find out the relationship between the independent variable (Non-Performing Loans) and dependent variable (Financial Performance) while linear regression analysis will be performed to investigate the impact of NonPerforming Loans on the Financial Performance for the period of 2012- 
2017. It is supported by the techniques used in the researches of (Rasika \& Sampath, 2015; Abiola \& Olausi, 2014).

The banking sector of Sri Lanka continued to dominate the financial sector, accounting for 60.3 per cent of the total assets of the financial sector and its performance remained robust during 2017. The banking sector continued to support economic growth and development by the enhanced banking services and the expansion of the banking network, thereby, promoting financial inclusion in the country (Central Bank report, 2017).

The present study is confined only to the nine listed commercial banks in Sri Lanka. The population of interest in this study is (initially) the 25 listed Licensed Commercial Banks on the Colombo Stock Exchange, as at February 2016.In selecting the population, the risk of missing data was minimized by excluding firms that were not listed throughout the review period. After the eliminations, nine Listed Commercial Banks remained in the population. Rasika and Sampath, 2015 only concerned six banks which includes two state bank and four private commercial banks from the population of 25 banks. Data analysis is done by the help of software package SPSS 22.0 and it is used for processing the data.
Sample of nine listed commercial banks use in this study are;

Commercial Banks of Ceylon PLC

$>$ DFCC Bank PLC

$>$ Hatton National Bank

$>$ Nation Trust Bank PLC

$>$ Pan Asia Banking corporation

$>$ Sampath Bank PLC

$>$ Seylan Bank PLC

$>$ Union Bank of Colombo PLC

$>$ Nation Development Bank

Return on Assets (ROA) and Return on Equity (ROE) is used as a measure of Financial Performance in the study it used as a measure in numerous studies (Abiola \& Olausi, 2014; Ali Sulieman Alshatti, 2015; Saeed MS \& Zahid N, 2016;Gizaw, Kebede, \& Selvaraj, 2015) Non-Performing Loans Ratio (NPLs ratio) is employed as the indicator of Non-Performing Loans of Banks. Gizaw, Kebede and Selvaraj, (2015); Noman, Pervin, Chowdhury and Banna, (2015) ; Rasika and Sampath, (2015) assert that Non-performing loans ratio is the prominent proxy for measuring NonPerforming loans of banks.

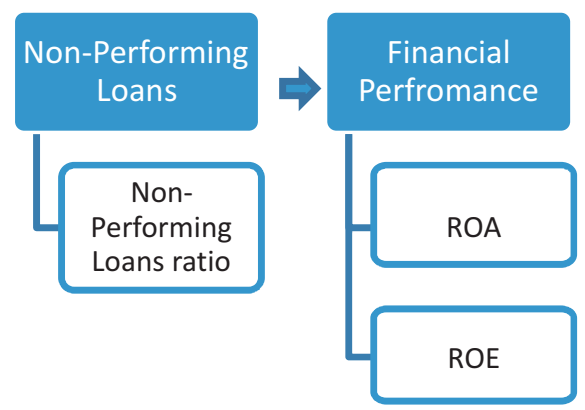

Figure 01: Conceptual Framework 
Table 01: Variables used in the study

\begin{tabular}{|c|c|c|c|}
\hline & & Measures & Symbols \\
\hline $\begin{array}{l}\text { Non } \\
\text { performin } \\
\text { g loans } \\
\text { variables }\end{array}$ & $\begin{array}{l}\text { Non } \\
\text { Performing } \\
\text { Loans ratio }\end{array}$ & $\begin{array}{l}\text { Non } \\
\text { Performing } \\
\text { Loans/ Total } \\
\text { loan }\end{array}$ & $\begin{array}{l}\text { NPLs } \\
\text { ratio }\end{array}$ \\
\hline \multirow{2}{*}{$\begin{array}{l}\text { Financial } \\
\text { Performan } \\
\text { ce } \\
\text { variables }\end{array}$} & $\begin{array}{l}\text { Returmon } \\
\text { Assets }\end{array}$ & $\begin{array}{l}\text { Net } \\
\text { income/Total } \\
\text { Assets }\end{array}$ & ROA \\
\hline & $\begin{array}{l}\text { Return on } \\
\text { Equity }\end{array}$ & $\begin{array}{l}\text { Net } \\
\text { income/Total } \\
\text { owners' } \\
\text { Equity }\end{array}$ & ROE \\
\hline
\end{tabular}

The impact of Non-Performing Loans on financial performance in this study tested with the following model:

$\mathrm{ROA}=\mathrm{a} 0+\mathrm{a} 1 \mathrm{NPLs}$ ratio........Model 01

$\mathrm{ROE}=\mathrm{b} 0+\mathrm{b} 1 \mathrm{NPLs}$ ratio........Model 02

Where, a0and b0 indicate the constant terms and al and b1are regression coefficients.

\section{Findings and discussions}

\subsection{Descriptive Analysis}

Table 02: Descriptive Statistics

\begin{tabular}{lcccc}
\hline & Min & Max & Mean & $\begin{array}{c}\text { Std. } \\
\text { Deviation }\end{array}$ \\
\hline NPLs & 1.31 & 15.25 & 3.98 & 2.63 \\
ratio & & & 1.3989 & 0.56 \\
ROA & 0.10 & 3.00 & 14.77 & 5.85 \\
ROE & 0.70 & 23.47 & 14 \\
\hline
\end{tabular}

According to the statistics it can be observed that the minimum Non Performing Loan ratio (NPL ratio) is 1.31 while maximum is 15.25 . But the mean of NPL ratio with 3.9 indicates that overall the banks in Sri Lanka have an improved asset quality. This also supports with the statement in Central Bank Report, 2017 that is "During the year the credit quality of the banking sector improved marginally, as reflected by the decline in the gross NPL ratio to 2.5 per cent as at end 2017, from 2.6 per cent as at end 2016".

\subsection{Regression Analysis}

Table 03: Model summary

\begin{tabular}{ccccc}
\hline Model & $\mathbf{R}$ & $\mathbf{R}^{\mathbf{2}}$ & $\begin{array}{c}\text { Adjusted } \\
\mathbf{R}^{\mathbf{2}}\end{array}$ & $\begin{array}{c}\text { F- } \\
\text { Statistics }\end{array}$ \\
\hline 1(ROA) & $0.294^{\mathrm{a}}$ & 0.086 & 0.069 & 4.909 \\
2(ROE) & $0.430^{\mathrm{a}}$ & 0.185 & 0.169 & 11.79 \\
\hline
\end{tabular}

Table 03 shows the model summary. Here for Model 01

$\mathrm{R}^{2}=0.086$
Adjusted $\quad \mathrm{R}^{2}=0.069$

In this model R2indicates that $8.6 \%$ of the ROA can be explained by the differences in the Independent variable (Non-Performing loans). The remainder $91.4 \%$ of the ROA is attributed to other factors. Here the value of an adjusted R2 is 0.069 , slightly less than the value of 0.086. The F-statistics and significance level shows that Model 01 generates statistically significant outcomes. 
Here for Model 02

$$
\mathrm{R}^{2}=0.185
$$

Adjusted $\mathrm{R}^{2}=0.169$

In this model R2indicates that $18.5 \%$ of the ROEcan be explained by the differences in the Independent variable (Non-Performing loans). The remainder $81.5 \%$ of the ROE is attributed to other factors. Here the value of an adjusted R2 is 0.169 , slightly less than the value of 0.185 . The F-statistics and significance level shows that Model 02 generates statistically significant outcomes.

Table 04. Result of regression analysis $($ Dependent variable $=$ ROA $)$

\begin{tabular}{ccccc}
\hline $\begin{array}{c}\text { Independent } \\
\text { variable }\end{array}$ & B & $\begin{array}{c}\text { Std. } \\
\text { Error }\end{array}$ & T & Sig. \\
\hline (Constant) & 1.652 & 0.136 & 12.10 & 0.000 \\
NPLs ratio & -0.063 & 0.029 & -2.21 & 0.031 \\
\hline
\end{tabular}

Table 05. Result of regression analysis (Dependent variable $=\mathrm{ROE}$ )

\begin{tabular}{ccccc}
\hline $\begin{array}{c}\text { Independent } \\
\text { variable }\end{array}$ & B & $\begin{array}{c}\text { Std. } \\
\text { Error }\end{array}$ & T & Sig. \\
\hline (Constant) & 18.583 & 1.324 & 14.035 & 0.000 \\
NPLs ratio & -0.953 & 0.278 & -3.435 & 0.001 \\
\hline
\end{tabular}

Table 05 . Result of regression analysis (Dependent variable $=$ ROE)

Table 04 presents the result of coefficient measure of Return on Assets (ROA). This indicates that NonPerforming Loans have the significant impact on ROA at 5\% Significance level. $\beta$ value for NPL ratio is -0.063 this explains that one unit increase in NPLs ratio will result a negative impact on ROA with 0.063 units. The analysis states indicator of Non-Performing Loans (NPL ratio) has the significant and negative impact on ROA.

Table 05 presents the result of coefficient measure of Return on Assets (ROE). This indicates that NonPerforming Loans have the significant impact on ROE at $1 \%$ Significance level. $\beta$ value for NPL ratio is -0.953 this explains that one unit increase in NPL ratio will result a negative impact on ROA with 0.953 units. The analysis states indicator of Non-Performing Loans (NPLs ratio) has the significant and negative impact on ROA.

Based on the results the models could be formulated as the Regression Equation follows;

ROA $=18.583-0.953$ NPL ratio

$\mathrm{ROE}=1.652-0.063 \mathrm{NPL}$ ratio

\subsection{Correlation Analysis}

Table 05: Correlation matrix of Variables

\begin{tabular}{|c|c|c|c|}
\hline Variables & NPLs ratio & ROA & ROE \\
\hline NPLs ratio & 1.000 & $\begin{array}{l}-0.294 * \\
(0.031)\end{array}$ & $\begin{array}{c}-0.430 * * \\
(0.001)\end{array}$ \\
\hline ROA & $\begin{array}{l}-0.294 * \\
(0.031)\end{array}$ & 1.000 & $\begin{array}{c}0.593^{* *} \\
(0.000)\end{array}$ \\
\hline ROE & $\begin{array}{c}-0.430 * * \\
(0.001)\end{array}$ & $\begin{array}{l}0.593^{* *} \\
(0.000)\end{array}$ & 1.000 \\
\hline $\begin{array}{l}\text { Correlati } \\
\text { tailed). }\end{array}$ & & & \\
\hline
\end{tabular}


Correlation analysis shows that there is a significant relationship between NonPerforming Loans ratio (NPLs ratio)and both Return on Equity (ROE) and Return on Assets (ROA). Results further indicate that the correlation between NPLs ratio and ROA is -0.294 . It clearly describes weak and negative relationship between NPLs ratio and ROA which is at the significance level of 5\%. Meanwhile correlation between NPLs ratio and ROE is -0.430 which is also denoted the negative relationship at significance level $1 \%$.

The analysis states that there is a negative and significant relationship between indicator of Non-Performing Loans (NPL ratio) and financial performance which is measured by ROA and ROE.

\subsection{Test of Hypothesis}

\section{Hypothesis of this study as follows:}

Hypothesis 1: There is a significant impact ofNon-Performing Loans on Financial Performance of Commercial banks in Sri Lanka.

From the analysis of Regression, Model 01 identifies, R2indicates that $8.6 \%$ of the ROA can be explained by the differences in the Independent variable (Non-Performing loans). The remainder $91.4 \%$ of the ROA is attributed to other
factors.Whereas Model 02 identifies, R2indicates that $18.5 \%$ of the ROE can be explained by the differences in the Independent variable (Non-Performing loans). The remainder $81.5 \%$ of the ROE is attributed to other factors.

Further, the result of coefficient measure of Return on Assets (ROA) and Return on Equity (ROE) indicate that NonPerforming Loans ratio has the significant impact on ROA and ROE at $5 \%$ and $1 \%$ Significance level respectively. Therefore $\mathrm{H} 1$ is accepted.

This conclusion comply with the researches of Kargi, 2011; Musyoki and Kadubo, 2012; Hosna, Manzura and Juanjuan, 2009; Gizaw, Kebede and Selvaraj, 2015.

Hypothesis 2: There is a significant relationship between Non-Performing Loans and Financial Performance of Commercial Banks in Sri Lanka.

Results further indicate that the correlation between NPLs ratio and ROA is -0.294 . It clearly describes negative relationship between NPLs ratio and ROA which is at the significance level of $5 \%$. Meanwhile correlation between NPLs ratio and ROE is -0.430 which is also denoted the negative relationship at significance level $1 \%$. 
The analysis states that there is a significant relationship between NonPerforming Loans ratio (NPLs ratio) and both Return on Equity (ROE) and Return on Assets (ROA).Therefore H2 is also accepted.

These findings comply with the researches of Samuel, O.L., 2015; Noman, Pervin, Chowdhury and Banna; Kolapo, Ayeni and Oke, 2012; Ebenezer and Omar, 2016; Rasika and Sampath, 2015 from Sri Lanka.

\section{Conclusion and recommendations}

\subsection{Conclusion}

This study aimed to investigate the significant impact of non-performing loans on financial performance and to identify the relationship between Nonperforming loans and Financial performance of Sri Lankan listed Commercial banks for the period of 2012-2017. With the use of descriptive, regression and correlation analysis the study has successfully achieved the objectives which it aimed at.

Commercial banks in Sri Lanka have been improved in the context of credit quality and they have been used to manage their capital adequacy at healthy levels from these past years. It could be concluded as non-performing loans has significant and negative impact on Financial Performance and there is a significant and negative relationship between non-performing loans and financial performance of commercial banks in Sri Lanka.

\subsection{Recommendations}

During the year the credit quality of the banking sector improved marginally, as reflected by the decline in the gross NPL ratio to 2.5 per cent as at end 2017, from 2.6 per cent as at end 2016 (Central Bank Report, 2017). This reflects that commercial banks in Sri Lanka are in the form of managing the credit risk at the safety level. But a quite number of banks which are growing now still face the problems of poor credit risk management practices.

The study suggests that the growing banks need to refocus on the effective management of its financial risk and devise new strategies like minimizing the lending rates and fee charges and critically assessing the customers who demand the extension of credit or loan before granting such, to reduce nonperforming loans will make an improvement in the financial Performance.

\subsection{Limitations of the study}

Due to the risk of missing data, only nine listed Commercial Banks remained in the population, so the sample size is not adequate in the study. Besides, data 
generated only for five years and it would be better if the research confined a long period of study.

\subsection{Directions for future research}

In the future studies, it should include the all the banks in Sri Lanka and the comparison researches between Sri Lanka and other countries would also be effective and beneficial to the personnel of Banks in order to enhance the performance by analyzing and explore new ideas from the techniques used by other countries.

\section{References}

Abiola, I., \&Olausi, A.S.(2014). The impact of credit risk management on the commercial banks performance in Nigeria. International Journal of Management and Sustainability, 3(5), p.295.

Abu Hussain, H., \& Al-Ajmi, J.(2012). Risk management practices of conventional and Islamic banks in Bahrain. The Journal of Risk Finance, 13(3), pp.215239.

Adeusi, S.O.,Akeke, N.I., Adebisi, O.S. \&Oladunjoye, O.(2014). Risk management and financial performance of banks in Nigeria. Risk Management, 6(31).

Ahmad, N. H., \&Ariff, M. (2007). Multicountry study of bank credit risk determinants. International Journal of banking and Finance, 5(1), 135-152.
Ali SuliemanAlshatti (2015). The effect of credit risk management on financial performance of the Jordanian commercial banks. Investment Management and Financial Innovations, 12(1-2)

Aruwa, S.A., \& Musa, O.A.(2014). Risk components and the financial performance of deposit money in Nigeria. International Journal of Social Sciences and Entrepreneurship, 1(11), pp.1-8.

Ebenezer, O.O., \& Omar, W.A.W.(2016). The Empirical Effects of Credit Risk on Profitability of Commercial Banks: Evidence from Nigeria. International Journal of Science and Research (IJSR). 5(8).

Gizaw, M., Kebede, M., \&Selvaraj, S. (2015). The impact of credit risk on profitability performance of commercial banks in Ethiopia. African Journal of Business Management, 9(2), pp.59-66.

Hosna, A., Manzura, B., \&Juanjuan, S.(2009). Credit risk management and profitability in commercial banks in Sweden. rapport nr.: Master Degree Project 2009: 36.

Kargi, H.S.(2011). Credit risk and the performance of Nigerian Banks. Ahmadu Bello University, Zaria.

Kithinji, A.M.(2010). Credit risk management and profitability of commercial banks in Kenya.

Kolapo, T.F., Ayeni, R.K., \&Oke, M.O.(2012). Credit Risk and Commercial Banks' performance In Nigeria: A Panel Model Approach. Australian journal of business and management research, 2(2), p.31. 
Lopez, J.A., \&Saidenberg, M.R.(2000). Evaluating credit risk models. Journal of Banking \& Finance, 24(1-2), pp.151165.

Musyoki, D., \&Kadubo, A.S. (2012). The impact of credit risk management on the financial performance of banks in Kenya for the period. International Journal of Business and Public Management, 2(2), pp.72-80.

Noman, A.H.M., Pervin, S., Chowdhury, M.M., \&Banna, H. (2015). The effect of credit risk on the banking profitability: a case on Bangladesh. Global Journal of Management And Business Research.

Rasika, D.G.L., \& Sampath, H.R.(2015). Impact of credit risk on financial performance of Sri Lankan commercial banks.
Saeed, M.S., \& Zahid, N.(2016). The impact of credit risk on profitability of the commercial banks. Journal of Business \& Financial Affairs, (5), p.192.

Samuel, O.L. (2015). The effect of credit risk on the performance of commercial banks in Nigeria. African Journal of Accounting, Auditing and Finance, 4(1), pp.29-52.

Van Gestel, T., \&Baesens, B. (2008). Credit Risk Management: Basic concepts: Financial risk components, Rating analysis, models, economic and regulatory capital. OUP Oxford. 